\title{
How Do Managers Think about Market Economies and Morality? Empirical Enquiries into Business-ethical Thinking Patterns
}

\begin{abstract}
How do managers think about the relationship between the pursuit of economic success and ethical demands? This paper presents the main results of a qualitative-empirical study (Ulrich and Thielemann, 1992). The range of thinking patterns displayed by Swiss managers in this field of tension is elucidated and typologized. The results are then compared with those yielded by other studies on managerial ethics. Although the comparisons reveal essential parallels, the findings of previous investigations are interpreted in a considerably different manner. In particular it is shown that, on the strength of a systematic conception of the fundamental problem of business ethics, the frequently heard assertion that the vast majority of managers are ethical opportunists must be revised. The internationally prevailing thinking pattern among managers does not prove to be ethical opportunism or even cynicism but economism, i.e, the ethical conviction that economically "appropriate" action in itself is ethically good as such.
\end{abstract}

\section{What is the fundamental problem of business ethics?}

"Are managers ethical or not?" (Posner and Schmidt, 1987: 383) or, in more moderate terms, "How ethical are businessmen?" (Baumhart, 1961) - this cardinal question is the explicit or implicit point of departure for most empirical enquiries into the "morals of

Peter Ulrich is Professor of Economic and Business Ethics and director of the Institute for Business Ethics at the University of St. Gallen (Switzerland). He is the author of several books (in German) on organization and management theory, and on the ethical foundations of economic thinking (among them Transformation der ökonomischen Vernunft, third ed. 1993).

Ulrich Thielemann is a doctoral student and a junior researcher at the Institute for Business Ethics. Together with Peter Ulrich he has recently published the book Ethik und Erfolg. Unternehmens - ethische Denkmuster von Führungskräften. managers". ${ }^{1}$ We will argue that this question, which would appear to have become habitual, is no suitable starting point for an enquiry into business ethics because it misses the fundamental, specifically business-ethical problem in a twofold manner right from the start:

First, the above-mentioned studies fell victim to a conventionalist reduction of their general theoretical approach by enquiring about the (quantitative) degree rather than the (qualitative) form of managers' moral consciousness. Most investigations into business ethics appear to be based on the assumption that there is a fixed canon of standards and rules which everyone has to comply with. This is why they speak of a "high level of ethical ideas" or of "high ethics" (Baumhart, 1961:12,19) in the sense of an actual readiness to adhere to such standards. They do not realize that concrete standards applicable to specific situations - in terms of Kohlberg's differentiation between conventional and postconventional levels of consciousness (1981: 152ff.) - are always to be regarded as conventional in nature, for at a postconventional level of moral judgement, standards are subject to hypothetical reservations. Correspondingly, the discussion of normative questions in a modern, pluralist society is controversial.

If the ethical consciousness of managers in the economy - a consciousness that may be postconventional, i.e. critical of prevailing conventions - is not to be undervalued by the very research approach, it will therefore not suffice to enquire about the approval or rejection of concrete ethical standards or values fielded by the researchers themselves. Instead, what must be identified and understood are the formal principles or the moral point of view from which the interviewee puts his case and accepts or rejects concrete standards as legitimate or illegitimate. This kind of looking at the problem requires an inter- 
pretative (hermeneutic) approach, as well as the researcher's readiness to be genuinely open to his interviewees' ethical arguments. In this context, a researcher must therefore not a priori arrogate any superior insight into a business-ethical point of view, or any exclusive competence to define "high business-ethical standards". Rather, he will have to make it his principle to assume that the interviewees are of equal ethical competence as the researcher himself. Thus they have to be acknowledged as rationally oriented persons, capable of arguing on moral questions. To neglect this general precondition of social science is to commit an objectivistic fallacy.

To presume ethical competence also implies the methodological presupposition that the interviewees will show "good will". At a postconventional level, which the social researcher, of course, has to hold, an alleged lack of "good will" may turn out to be an instance of incomprehension in the face of an interviewee's specific claim to legitimation. The assumption of an interviewee"s ethical competence and of an ethical will is thus a necessary research basis which, of course, may be empirically refuted in individual cases. Yet how else could a researcher be able to understand managers' business-ethical concepts of reconciliating ethical demands with the requirements of profit seeking - particularly in view of the fact that these concepts may well deviate from the researcher's own ideas? This crucial qualitative formulation of the problem provides an immediate link with the second conceptual deficit of the usual starting question, which refers to the demarcation of business ethics as a research object.

Second, the above-mentioned studies invariably suffer from a personalist reduction of the fundamental problem of business ethics in that they systematically abstract from the complex economic circumstances of managerial action. In this fashion, the basic question as to the "locus" of ethics in the economy is actually answered in advance since the approach presumes that it is solely a question of managers' personal morality. ${ }^{2}$ As we shall see, however, the majority of the managers interviewed do not see the primary "locus" of economic ethics in the individual manager's personal conscience but in the market or in its political framework.

If a conception of the fundamental problem of business ethics is to be adequate and to do justice to reality, then it must not only take into account the "purely" ethical aspect but also the economic side of managers' role-specific decision-making problems. Business ethics as a scientific discipline would be pointless if it did not take as its point of departure precisely those particular ethical realization conditions and problems that arise within the framework of a modern economic system. It is clear that ethical demands must not simply be subordinated to economic rationality; after all, it is the essence of ethics to make unconditional demands on us. Yet ethical demands must not jeopardize a company's continued economic success without any reservations, either; such heroic idealism would be economically unimposable. As everyone knows, a company that is incapable of satisfying the requirements of the market will disappear from the scene (i.e. the market) before long, which in turn will again cause complex ethical problems if, say, staff have to be made redundant. We therefore formulate the fundamental problem of business ethics as follows:

How do managers reconcile the requirements of achieving and preserving managerial success with the ethical demands of which they as responsible persons are, or ought to be, aware?

Thus in our view, the systematic starting question for any fruitful empirical research into business ethics is not simply whether or to what extent managers are "ethical", but what kind of thinking pattern they have personally evolved for themselves in order to be able to legitimize their activities within the field of tension between ethics and economic success both before themselves and before others. We suppose - not only for methodological, but also for psychological reasons - that top managers at least will, as a rule, have come to some sustainable business-ethical "arrangement" for themselves. After all they, like most other people, would like to be "at peace" with themselves and to be able to hold their own in the face of critical questions asked by both their nearest and dearest and the general public. Those who have not come to a subjectively sustainable arrangement would hardly have chosen a manager's career, or would sooner or later have "dropped out" of it in order to resolve their unendurable inner tensions. Thus successful managers in particular may fundamentally be credited with a claim to ethical legitimation (and with the readiness to honour it in their arguments). For this reason, it 
makes methodological sense to assume the hypothesis that managers usually have business-ethical thinking patterns they can sustain with regard to themselves (i.e. within their frame of reference).

Since, as indicated, interconnections between economic success and ethical demands are extremely varied and intricate, it may be useful to suppose a plurality of such thinking patterns and "arrangements" that managers apply in the field of tension between ethical and managerial aspects. This is why it makes little sense to search for an "average ethical profile", as has so far been done more or less explicitly by virtually all the studies on this topic. Rather, the proper research objective consists in elucidating the whole range of existing thinking patterns and in typologizing them according to systematic criteria. As Max Weber showed in his remarks on the typological method of interpretative social research as early as 1904 (esp. p. 175f.), the criteria that may be used for this purpose cannot also be directly derived from the empirical data but must emerge from a research concept that is based on theory.

Moreover, it has to be borne in mind that like their interviewees, researchers who intend to study executives' business-ethical consciousness always introduce a certain prior understanding of the relationship between ethics and the pursuit of managerial success and may unreflectingly use it as a "given" theoretical frame of reference - unless they deliberately examine alternative criteria. An appropriate selection of the systematic aspects (dimensions) used to typologize the plurality of individual argumentation patterns follows the idea of a "reflective equilibrium", to be realized step by step, between the practical problem conceptions requiring explanation and the theoretical, i.e. critical reconstruction of the principles governing practice, as developed by John Rawls (1971: 20f,, 48-51). Thus, we claim that our theoretical framework, presented in Section 2, is neither imposed on nor simply taken from but rationally connected to managerial thinking as empirically found.

This theoretical conception, i.e. the reflection of the frame of reference, is exactly what distinguishes a scientific from an everyday's life interpretation. It helps to get a deeper understanding of existing thinking patterns and corresponding action patterns by elucidating the good reasons such convictions are subjec- tively based on. "Only to the extent that the interpreter grasps the reasons that allow the author's utterances to appear as rational does he understand what the author could bave meant" (Habermas, 1984: 132). Understanding is interrelated to critique.

Thus, a critical examination of the types of business-ethical responsibility that have been conceived of and empirically established in this manner may finally result in new perspectives of normative business ethics. It is for this reason that we also regard the proposed approach as an essential contribution towards a conceptualization of businessethical precepts that will be sustainable, i.e. ethically justifiable and at the same time economically imposable in practical working life.

Our empirical study was conceived in keeping with the research design whose general outlines have been sketched out above. It was then conducted in accordance with the methodological guidelines of interpretative (qualitative) social research. Of the 75 persons originally addressed, 60 executives from private companies of all sizes agreed to be interviewed. They were chiefly top managers, and both sexes were represented. (The unusually high quota of $80 \%$ willing to participate in the project may well be regarded as an early corroboration of our psychological and methodological assumption that managers do have a claim to ethical legitimation). The selection was not statistically representative but deliberately aimed at the inclusion of as wide a range of business-ethical thinking patterns as possible. ${ }^{3}$ This is due to our research interest in understanding and elucidating what is the case in managers' thinking about business ethics, rather than in how these characteristics are statistically spread. Statistics are second order questions. Nevertheless, we regard the figures we will present as first hints at tendencies, at least for Swiss business executives.

The interviews were intensive in character, lasted between one to four hours, took their bearings from partially standardized guidelines, and were taped in order to enable a careful, and frequently repeated, interpretation. There was not any "method" in learning to understand how the managers think about business-ethics. As already indicated, hermeneutical investigations imply an at least virtually argumentative (discoursive) engagement with the "object" of research. And there are not any "techniques" of argumentation at all, because arguing means to give 
good reasons, no more and no less. We hope that our interpretation of the thinking patterns we have found is based on such good reasons that might be plausible in the context of history of thought we shall start from (rather than from statistics!).

After presenting the theoretical framework, we will turn to the most significant result of this study, namely the business-ethical thinking patterns themselves, at first, before moving on to a critical reinterpretation of the previous research results presented by Baumhart and his successors.

\section{A typology of business-ethical thinking patterns}

In the sense of the postulated methodological idea of a "reflective equilibrium", and after a detailed examination of a wide variety of possible systematization criteria, two fundamental dimensions of businessethical ways of thinking were found to be particularly helpful with regard to the classification and assessment of qualitatively diverging replies. Each of these dimensions has two manifestations.

\section{Dimension 1: Degree of problem and conflict awareness}

Depending on which of the two manifestations is prevalent, business ethics is either perceived as a problem and an actual challenge or not.

- Either it is assumed that as a rule, there is harmony between the pursuit of managerial success and ethical aspects. In this case, we speak of harmonists. It must then be asked what kind of guarantor is capable of providing such assumed harmony and how this authority is capable of legitimizing the corporate policy pursued.

- Or it is assumed, conversely, that the relationship between ethics and the pursuit of success is characterized by conflict (conflict perceivers). In this case, harmonization remains to be attained, and it must be asked how this is possible and who would assume responsibility for it.
Dimension 2: The way in which the economy is perceived

It largely depends on this dimension how a state of harmony or conflict is justified.

- Either the economy is perceived as a relatively autonomous system which mainly follows its own functional logic. In this case it is ultimately the anonymous market mechanisms that determine what happens in the economy. Individual economic subjects are largely confined to adapting themselves to the market system's competitive conditions: if they want to participate in the economic "game" of holding their own in the marketplace, then they have to stick to its rules. It must then be asked whether the morality of the economic game is assumed to be intrinsic to "free markets" as such or to be established by the market's political framework.

- Or else the economy is perceived as a sphere of life like any other, as a normal part of the world we live in, which is basically not determined by anonymous system imperatives but by the prevailing economic culture (for the differentiation between lifeworld and system as sociologically fundamental categories, $\mathrm{cf}$. Habermas, 1987: 148ff., 232ff.; 1986: 379ff.). In the view of culture-oriented managers, the economy is neither ascribed to a special "ethic-free" functional logic, nor is any particular ethics of the economic system called for: solely the application of the general yardsticks of moral action is required. In this case, the question is whether these moral yardsticks are to be attributed to a conventional or postconventional awareness of ethics.

From a "theoretical" perspective, four basic types of business-ethical thinking can now be derived from the two-dimensional matrix resulting from a "crossing" of the two dimensions and their respective two aspects. (s. Fig. 1).

In order to provide a first survey, Fig. 1 also indicates the frequency of the thinking patterns subsumed in the four groups which we call basic types. This frequency, however, merely refers to the distribution of the dominant (primary) orientation in each case. Above and beyond this it turned out that virtually all interviewees' business-ethical concepts 


\begin{tabular}{|c|c|c|}
\hline Dim. 1 & $\begin{array}{c}\text { System-oriented } \\
44 \%\end{array}$ & $\begin{array}{c}\text { Culture-oriented } \\
56 \%\end{array}$ \\
\hline $\begin{array}{c}\text { Harmonists } \\
88 \%\end{array}$ & $\begin{array}{c}\text { Metaphysical } \\
\text { Economists } \\
34 \%\end{array}$ & $\begin{array}{c}\text { Conventionalists } \\
54 \%\end{array}$ \\
\hline $\begin{array}{c}\text { Conflict } \\
\text { Perceivers } \\
12 \%\end{array}$ & $\begin{array}{c}\text { Reformers } \\
10 \%\end{array}$ & $\begin{array}{l}\text { Ilealists } \\
\qquad 2 \%\end{array}$ \\
\hline
\end{tabular}

Fig. 1. Basic types of businessmethical concepts.

were also characterized by additional (secondary) orientations. These will be referred to in more detail in Section 3. The basic types and the more tangible thinking patterns (real types) assigned to them will be outlined very briefly below. A detailed representation and interpretation of the different thinking patterns and their distribution according to a number of criteria can be found in the book published on this study (Ulrich and Thielemann, 1992: 33ff.). A tabular survey of the various types, as well as a brief characterization in a systematic cross-comparison, is provided by Fig. 2 below.

\section{(a) The economistic arrangement}

As a rule, Metaphysical Economists assume that there is harmony between ethics and economic success; at the same time, they perceive the marketplace as an anonymous system. Yet they evidently do not regard this as an ethical problem: they place more confidence in the "rationality" of the economic system than in human beings' practical reason. Not responsibly acting people, but the structural interrelations of anonymous market occurrences themselves ensure that the economy takes its proper course. If single moral snags occasionally occur in economic activities nonetheless, then a strict metaphysical economist will, on principle, consider them a symptom of the fact that the influence of the market forces is too slight rather than too strong. Like any other metaphysics, his market metaphysics are not at all easy to refute along empirical lines.
The belief in a market-inherent moral reason has deep roots in the history of thought of the occidental market society (cf. Ulrich, 1987: 180ff.). Originally, it is religious in nature. This is the belief in the "prestabilized harmony" (Leibniz) of the world and market order given by a superhuman agency, i.e. God. Its "invisible hand" (Adam Smith, 1976a: 184; 1976b: 456) guarantees that what we should do in terms of ethics will "automatically" grow from what we want to do in economic terms. In this fashion, individual economic subjects are relieved of any direct normative-ethical demands. In Adam Smith (1976a: 87), this "invisible hand" can still easily be identified as the "wisdom of God". Thus Smith, who stood on the threshold of modernity, is likely to have been the first and last economist for whom the market's power to harmonize interests was still more or less explicitly based on metaphysics (cf. Ulrich, 1991: 175ff.). "Modern" versions of market harmonism, however, have long been oblivious of their own metaphysical roots - otherwise, such views could hardly be held today, particularly in their more distinctive forms of more or less "blind" market worship.

According to our study, the economistic belief in the market's "self-healing powers" can be found among two variants of executives who differ with regard to strictness. In the case of the Metaphysical Manager, as we call this type (17\% of our sample), the market's impersonal and "superhuman" intrinsic morality is, as it were, spontaneously translated into the "appropriate" practice of management. Ultimately, the Metaphysical Manager is convinced that an enterprise is not moved by human beings, but by the "will of the market". Executives are only tools of the market and, when all is said and done, possess no power at all - at least to the extent to which they seek to boost their companies" permanent profitability stakes by banning any "non-corporate interests" (Weber, 1972: 79). Consequently, they cannot be held responsible for any ethical deplorable states of affairs: if you don't have power, you can't exercise it, and ethics doesn't as much as come into it. One of the managers interviewed expressed this as follows: ${ }^{5}$ "only a human being can act ethically or unethically, but a company...? Even if the person who runs a company is unethical, this does not mean that the company is unethical, too." The market tells the executive what's what, and that's how it should be. 


\begin{tabular}{|c|c|c|c|c|}
\hline \multirow[t]{2}{*}{ Type } & \multicolumn{2}{|l|}{ Economism } & \multicolumn{2}{|l|}{ Conventionalism } \\
\hline & $\begin{array}{l}\text { The Metaphysical } \\
\text { Manager }\end{array}$ & $\begin{array}{l}\text { The Instru- } \\
\text { mentalist }\end{array}$ & The Paternalist & The Personalist \\
\hline $\begin{array}{l}\text { Way of } \\
\text { reconciliation }\end{array}$ & $\begin{array}{l}\text { Impersonal market } \\
\text { control }\end{array}$ & $\begin{array}{l}\text { Sound and clever } \\
\text { profit seeking }\end{array}$ & $\begin{array}{l}\text { Ethical authority } \\
\text { and consideration } \\
\text { of entrepreneurs }\end{array}$ & $\begin{array}{l}\text { Social responsi- } \\
\text { bility of } \\
\text { executives }\end{array}$ \\
\hline Resulting action & $\begin{array}{l}\text { Relief of manage- } \\
\text { ment from } \\
\text { demand of ethical } \\
\text { reflection }\end{array}$ & $\begin{array}{l}\text { Use of ethics as } \\
\text { a management } \\
\text { instrument }\end{array}$ & $\begin{array}{l}\text { Charismatic lead- } \\
\text { ership ("model" } \\
\text { behaviour, "set } \\
\text { examples") }\end{array}$ & $\begin{array}{l}\text { Ethics as an } \\
\text { "accompanying } \\
\text { factor" of } \\
\text { management }\end{array}$ \\
\hline Justification & $\begin{array}{l}\text { Long-term econ- } \\
\text { omy = ethics; } \\
\text { neutralization of } \\
\text { entrepreneurial } \\
\text { power by the } \\
\text { market }\end{array}$ & $\begin{array}{l}\text { Ethics = long- } \\
\text { term economy; } \\
\text { this is regarded as } \\
\text { a sign of harmony } \\
\text { between success } \\
\text { and ethics }\end{array}$ & $\begin{array}{l}\text { Superior ethical } \\
\text { competence of } \\
\text { management }\end{array}$ & $\begin{array}{l}\text { Power implies } \\
\text { responsibility }\end{array}$ \\
\hline $\begin{array}{l}\text { Subject } \\
\text { responsible }\end{array}$ & $\begin{array}{l}\text { Invisible band of } \\
\text { the market }\end{array}$ & $\begin{array}{l}\text { Ultimately, in- } \\
\text { visible hand of the } \\
\text { market }\end{array}$ & $\begin{array}{l}\text { Entrepreneur as } \\
\text { paterfamilias }\end{array}$ & $\begin{array}{l}\text { Entrepreneur/ } \\
\text { manager as } \\
\text { decision-maker }\end{array}$ \\
\hline $\begin{array}{l}\text { Symptomatic } \\
\text { expression }\end{array}$ & $\begin{array}{l}\text { "There is no } \\
\text { ethical or unethical } \\
\text { management." } \\
\text { "Everyone will do } \\
\text { well if the com- } \\
\text { pany does well." }\end{array}$ & $\begin{array}{l}\text { "Ethics can be a } \\
\text { key success factor } \\
\text { - if you handle it } \\
\text { right." }\end{array}$ & $\begin{array}{l}\text { "Management must } \\
\text { instil ethics from } \\
\text { above." }\end{array}$ & $\begin{array}{l}\text { "I plead for an } \\
\text { absolutely liberal } \\
\text { business policy which } \\
\text { must, however, be } \\
\text { placed under man- } \\
\text { agerial self-control." }\end{array}$ \\
\hline Criticisms & $\begin{array}{l}\text { The metaphysics } \\
\text { of the market } \\
\text { - Rigorism }\end{array}$ & $\begin{array}{l}\text { - Reduction of } \\
\text { ethics to "good } \\
\text { management" } \\
\text { - Overlooks con- } \\
\text { flicts between } \\
\text { the economy } \\
\text { and ethics (har- } \\
\text { monious world) }\end{array}$ & $\begin{array}{l}\text { - Elitism } \\
\text { - Low awareness } \\
\text { of economic } \\
\text { system } \\
\text { - Fiction of } \\
\text { corporate } \\
\text { community } \\
\text { represented by } \\
\text { the entrepreneur }\end{array}$ & $\begin{array}{l}\text { Monological } \\
\text { concept of } \\
\text { responsibility } \\
\text { - Low awareness } \\
\text { of economic } \\
\text { system }\end{array}$ \\
\hline $\begin{array}{l}\text { Incidence } \\
\text { - dominent: } \\
\text { - additional: } \\
\text { - total }\end{array}$ & $\begin{array}{r}17 \% \\
7 \% \\
24 \%\end{array}$ & $\begin{array}{l}17 \% \\
35 \% \\
52 \%\end{array}$ & $\begin{array}{l}13 \% \\
15 \% \\
28 \%\end{array}$ & $\begin{array}{l}38 \% \\
22 \% \\
60 \%\end{array}$ \\
\hline $\begin{array}{l}\text { Alternative } \\
\text { tendency }\end{array}$ & $\begin{array}{l}\text { Personalism }(60 \%) \\
\text { Legalism }(40 \%)\end{array}$ & Personalism $(70 \%)$ & Not ascertainable & $\begin{array}{l}\text { Instrumentalism } \\
(26 \%)\end{array}$ \\
\hline
\end{tabular}

Fig. 2. Types of business-ethical thinking. 


\begin{tabular}{|c|c|c|c|c|}
\hline & & Idealism & Reformism & \\
\hline $\begin{array}{l}\text { The Cultural } \\
\text { Harmonist }\end{array}$ & The Legalist & The Idealist & $\begin{array}{l}\text { The Framework } \\
\text { Reformer }\end{array}$ & $\begin{array}{l}\text { The New } \\
\text { Entrepreneur }\end{array}$ \\
\hline $\begin{array}{l}\text { Commitment to } \\
\text { social conventions }\end{array}$ & $\begin{array}{l}\text { Legally enacted } \\
\text { law }\end{array}$ & $\begin{array}{l}\text { Change in social } \\
\text { awareness and } \\
\text { values }\end{array}$ & $\begin{array}{l}\text { Politics of } \\
\text { economic order }\end{array}$ & $\begin{array}{l}\text { A two-level } \\
\text { business-ethical } \\
\text { concept }\end{array}$ \\
\hline $\begin{array}{l}\text { Accomplish the } \\
\text { "social commission" }\end{array}$ & $\begin{array}{l}\text { Compliance with } \\
\text { applicable legis- } \\
\text { lation }\end{array}$ & $\begin{array}{l}\text { Renunciation } \\
\text { of "unethical } \\
\text { success", appeal } \\
\text { to individuals }\end{array}$ & $\begin{array}{l}\text { 1st level: "business } \\
\text { as usual" } \\
\text { 2nd level: co- } \\
\text { responsibility re } \\
\text { politics of } \\
\text { economic order }\end{array}$ & $\begin{array}{l}\text { 1st level: search } \\
\text { for profitable } \\
\text { ways of ethical } \\
\text { managment } \\
\text { 2nd level: co- } \\
\text { responsibility re } \\
\text { politics of eco- } \\
\text { nomic order }\end{array}$ \\
\hline $\begin{array}{l}\text { The company is } \\
\text { "part of society" }\end{array}$ & $\begin{array}{l}\text { Legitimacy = } \\
\text { legality }\end{array}$ & $\begin{array}{l}\text { "Egoism" and } \\
\text { "materialism" can } \\
\text { only be curbed } \\
\text { through individual } \\
\text { self-discipline. }\end{array}$ & $\begin{array}{l}\text { "Companies only } \\
\text { develop this to the } \\
\text { desired extent under } \\
\text { government } \\
\text { pressure." }\end{array}$ & $\begin{array}{l}\text { Syntheses of ethics } \\
\text { and success as } \\
\text { entrepreneurial } \\
\text { challenge and as a } \\
\text { mission to remodel } \\
\text { the ecnomic order }\end{array}$ \\
\hline $\begin{array}{l}\text { Members of the } \\
\text { cultural community }\end{array}$ & $\begin{array}{l}\text { Legislative } \\
\text { (state) }\end{array}$ & $\begin{array}{l}\text { Committed } \\
\text { persons }\end{array}$ & $\begin{array}{l}\text { Governmental } \\
\text { politics shaping the } \\
\text { economic order }\end{array}$ & $\begin{array}{l}\text { "Enlightened man- } \\
\text { agers" as members } \\
\text { of the public } \\
\text { sphere }\end{array}$ \\
\hline $\begin{array}{l}\text { "The company is } \\
\text { bound up with } \\
\text { society and its } \\
\text { principles." }\end{array}$ & $\begin{array}{l}\text { "We always subject } \\
\text { ourselves to the } \\
\text { laws of the country } \\
\text { in which we } \\
\text { operate." }\end{array}$ & $\begin{array}{l}\text { "The free market } \\
\text { economy would be } \\
\text { wonderful if there } \\
\text { were ideal people." }\end{array}$ & $\begin{array}{l}\text { "I have nothing } \\
\text { against a strict } \\
\text { legislative environ- } \\
\text { ment if I can still } \\
\text { usefully operate } \\
\text { inside it." }\end{array}$ & $\begin{array}{l}\text { "It is an entrepre- } \\
\text { neurial challenge to } \\
\text { deal with ethical } \\
\text { demands in a spirit } \\
\text { of innovation." }\end{array}$ \\
\hline $\begin{array}{l}\text { - Outdated sup- } \\
\text { position of a } \\
\text { "closed society" } \\
\text { - Rigid code of } \\
\text { values }\end{array}$ & $\begin{array}{l}\text { - Uncritical legal } \\
\text { positivism } \\
\text { - Business-ethical } \\
\text { passivity } \\
\text { - Cannot be } \\
\text { generalized }\end{array}$ & $\begin{array}{l}\text { - Lack of an } \\
\text { institutional } \\
\text { perspective } \\
\text { - Ethics of } \\
\text { renunciation }\end{array}$ & $\begin{array}{l}\text { - Understanding } \\
\text { of business } \\
\text { ethics "cut in } \\
\text { half" } \\
\text { - Partial eco- } \\
\text { nomism (within } \\
\text { the economic } \\
\text { framework) }\end{array}$ & - None \\
\hline $\begin{array}{r}3 \% \\
7 \% \\
10 \%\end{array}$ & $\begin{array}{r}0 \% \\
12 \% \\
12 \%\end{array}$ & $\begin{array}{r}2 \% \\
38 \% \\
40 \%\end{array}$ & $\begin{array}{r}2 \% \\
20 \% \\
22 \%\end{array}$ & $\begin{array}{r}8 \% \\
5 \% \\
13 \%\end{array}$ \\
\hline $\begin{array}{l}\text { Instrumentalism } \\
(67 \%)\end{array}$ & Does not apply & Resignation & Economism & None \\
\hline
\end{tabular}


The lasting assurance of a company's existence and success requires far-sighted long-term investments, not merely a "speculative" maximization of short-term profits. Only this will ensure that management action will indeed be determined by the literally "suprapersonal" (anonymous) will of the market rather than by the "arbitrary" will of the managers themselves. Thus the business-ethical principle applies according to which long-term profit is ethically good. Then, however, the "invisible hand" of the market will ensure that "everyone will do well if the company does well".

In such conditions, the proper way to run an enterprise must be inferred from the company's success in the market alone, especially for reasons of ethical responsibility - or as Milton Friedman (1970) famously put it: "The social responsibility of business is to increase its profits" (and nothing else). It verges on the "unethical" to have subjective value judgements interfere with market-intrinsic ethics, whereas it is "ethical" to follow the signals of the market and thus to "discover" ethically appropriate courses of action. As a consequence - and this is the key point of this thinking pattern - entrepreneurs and managers have to abstain as far as possible from any personal moral sentiments and value judgements and listen to the "objective" verdict of the market instead.

In contrast to the Metaphysical Manager, the Instrumentalist (again 17\%, but recorded as an additional orientation with another $35 \%$ ), is perfectly ready to admit ethical considerations as an element of management. Indeed, he even calls for them since he does not necessarily regard them as a departure from the virtuous path of managerial profit seeking. This is why his reconciliation concept appears to be more moderate than the rigoristic concept of the Metaphysical Manager, who must refrain from any personal and thus from any moral commitment within the economy precisely for ethical reasons. The Instrumentalist, however, casts himself in a more active role in this respect: he "discovers" and realizes the strategic potential of "ethics" as an investment. Thus the economistic principle of legitimation is apparently inverted: ethics is long-term profit. Or, in the words of a manager we interviewed: "Ethics may even be a key success factor - if you handle it right."

Thus the Instrumentalist's primary incentive to act "ethically" is not an inner conviction. Rather, he acts in this manner because (and insofar as) such a course of action will pay off in the long run. He therefore avails himself of ethics as a management instrument for, say, the motivation of his staff or in order to ensure that his corporate policy gains acceptance among the general public. He does not attempt to conceal the instrumental character of such management methods but actually emphasizes his economic motivation. Nevertheless, instrumentalism in this sense of the term must be conceived of as a business-ethical concept. Indeed, the fact that calculations with regard to long-term corporation profitability involve "ethics" is seen as a sign of basic harmony between the pursuit of economic success and ethical demands. Here, too, it is assumed that an "invisible hand" is at work in the market which provides the executives' profit-oriented action with an ethically appropriate sense of direction.

This signal character of market success is strongly reminiscent of the connection elaborated by Max Weber in his famous paper (1920) between the specifically religious motives of Protestantism, particularly of Calvinism and Puritanism, and the "Spirit of Capitalism". The (Calvinist) entrepreneur subjects himself to the methodical discipline of "ceaseless work" (p. 105), striving for professional and market success because this is the only way in which he is able to overcome the unendurable uncertainty of whether God will grant him His Divine mercy, of whether he may be hopeful of "salvation" in the hereafter. He considers professional success as an unfailing "sign of being chosen" (p. 110) - not, however, as a high-handed "means of attaining salvation" (p. 110). It is therefore not human intentions and motives that he discerns "at work on all that occurs in life", but a mighty and omniscient God; and if this God "shows one of his people a profitable chance, then He will do so by intention" (pp. 175ff.), namely the intention of assuring him that he is in a state of grace.

In our view the parallels with the two versions of economism, which like "Protestant ethics" advocate a revelation theory of the market, are evident. Indeed we suspect that the historical roots of economism are religious in nature and lie in the Protestantism from which Max Weber saw the "spirit of capitalism" emerge. It would appear that those "modern" managers who believe in economism still rely on 
the "signs and tokens" of success even if their secularized consciousness has long discarded any religious motives.

\section{(b) The conventionalist arrangement}

Conventionalists, too, perceive a basic harmony in the relationship between ethical demands and the pursuit of economic success. Their reconciliation concept contrasts with the economistic one - at least on the surface - in that management ethics is not guaranteed by an anonymous system logic intrinsic to the market. Instead, it makes use of the general standards that have been handed down and also apply to daily life in general. Systemic constraints of profitability do not play any systematic role in Conventionalists' arguments - neither a harmonizing nor a problematic role. This is not because Conventionalists simply negate or repress these economic constraints, but because they perceive them in completely different categories. Should it still come to a concrete conflict between ethics and economic success, Conventionalists will not apprehend this as a structural antagonism between moral obligation and systemic constraint but, in terms of individual ethics, as a conflict between moral obligation and egoistic predilection or economic self-interest. Thus conventionalists are not overly bothered by free-rider problems, as they do not perceive the systemic character of the modern economy. Rather, they see the key to a guaranteed harmony between ethics and the market in the character of individual execurives or - in the case of less élitist versions of conventionalism - in the cultural standards of the community of economic agents.

There is a variety of conventionalistic thinking patterns (real types) which differ from each other in their distinctive concepts of the cultural "locus" of ethics. Since these distinctions do not play any particular part in this text, they will only be indicated in brief.

For the thoroughly value-conservative Paternalist $(13 \%)$, the company still retains something of an internally hierarchic - oikos economy, whose fortunes he controls with a strict and considerate hand. He does not doubt his authority, which in his overall view of things is a matter of course. His sense of responsibility is thus linked with a self-conception of élitist tendencies and therefore remains uncritical in this respect.

The Personalist (with 38\% the most frequent dominant orientation) is more strongly aware of his power, of the danger of its egoistic misuse, and thus of the fact that such power requires legitimation. Yet he primarily perceives this business-ethical challenge in terms of limiting such powers himself rather than of subjecting them to social control; as for the rest, he pleads for "absolutely liberal business policies". His individually ethical or élitist approach is also evident in that he prefers to put the stress on managers' personal ethics rather than on business ethics in general. The notion of ordo-political support for any business-ethical commitment is alien to him (despite the real economic constraints and all the opportunities of free-riding) since he resolutely adheres to the idea of the separability of "private" economy from public politics.

By contrast, the Cultural Harmonist's (3\%) thinking pattern is based on the idea that the company "is bound up with society and its principles". He conceives of society as a more or less conflict-free unit held together by a generally recognized value system. As a consequence, ethical demands to be made on management are best satisfied by an adherence to "the well-known basic ethical standards".

Conversely, the legalist (not found as a dominant orientation but recorded as a secondary one with no less than 12\%) does not think of ethics as directly guaranteed by the culture of society, but by the constitutional state in the form of applicable laws (legal standards). He considers the legality of management to be the necessary, and at the same time sufficient condition for the legitimacy of management.

\section{(c) The idealistic arrangement}

In a marked contrast to both Conventionalists and Metaphysical Economists, the Idealist regards the pursuit of profit as highly problematic in ethical terms. ${ }^{7}$ The Idealist is distinctively aware of conflict, but not particularly system-conscious in his perception of the economy. He is critical of contemporary culture rather than of the actual market system. In his view, then, social or ecological issues he deplores are not the consequence of any anonymous market 
forces, but rather the result of the "egoism" and "materialism" which all too many economic subjects have fallen prey to. He regards the dominating cultural attitudes and codes of values as the actual problem, unlike the Cultural Harmonist, who regards them as the solution. Precisely for this reason, the Idealist hopes for a profound change in cultural consciousness.

Since the Idealist thinks in terms of individual ethics rather than systemic categories, his champion way of assuming responsibility is the individual's renunciation of her "egoistic" predilections. In the face of the real factual constraints of the cconomic system, however, this means that the Idealist provided she does not "drop out" - is permanently exposed to tough ethical dilemmas between idealistic commitment and opportunism. This may explain the heroic pathos that is apt to accompany his comments ("holding your ground in this conflict is part of the job"). For the Idealist, this conflict between ethical demands and the pursuit of market success is ultimately insoluble: his business-ethical commitment is literally at the expense of the company's success. In this manner, however, his business ethics is characterized by a spirit of renunciation. It could be described as a "red-figure ethics" (Pfriem, 1989: 118) which does not do justice to the problem of the economic imposability of measures justified by ethical reasons. Such kind of business ethics can therefore hardly be considered sound management.

\section{(d) The reform-oriented arrangement}

The point of departure of the Reformers' businessethical reconciliation concept is the plain but reasonable view that ethics and success are neither locked in inevitable conflict, nor do they automatically enjoy a harmonious relationship. Rather, reformers recognize the opportunity that ethics may well be a basis of successful enterprise. Whether and in what conditions this is the case is regarded as an empirical question that can only be answered by means of a sober and differentiated analysis of the concrete problems to be solved.

Reformers are aware of ethical conflicts and functional constraints. They are critical of existing system constraints because they regard the Idealists' demands to do heroic battle against the signals of the market as exorbitant. In their view, the crucial prerequisite to put the manager's ethical responsibility into practice is a change in the ordo-political framework of markets, i.e. in the general rules and incentives for successful economic activities. Of course, these rules of the game have to be determined in a societally responsible and competition-neutral way.

One type of Reformer, the mete Framework Reformer (2\%), sees the systematic locus of business ethics in an arrangement of the market's general conditions and rules alone, but not in any ethical considerations within these rules. Within a reasonable market's framework, "business as usual" has to take place. Thus the Framework Reformer pleads for ethical considerations on the level of the political framework of markets exactly in order to keep business activities free from ethical claims.

The other type of Reformer, whom we call the New Entrepreneur (8\%), applies a managerial thinking pattern that is both more extensive and more differentiated. He has learnt to think in terms of two institutional levels at once. On the first level he discerns considerable creative scope for the attainment of business success which - like any other scope of action - can and should be exhausted in an ethically responsible manner. The New Entrepreneur thus considers it a "managerial challenge to deal with the new ethical demands in a spirit of innovation". Therefore, he takes the trouble to look for syntheses of ethics and success that are apt to be unconventional.

Being a realist, however, the New Entrepreneur is aware of the limits of such a degree of commitment at the level of a singular company. This is why on the second level, he reflects upon the structural reform of the general framework of the market system itself - not least also in the company's enlightened "selfinterest". Reformers, and New Entrepreneurs in particular, thus ask critical questions about the ethical quality of the existing economic system with a view to business-ethical integration: their intention is to give the manager's economic concern an implicitly ethical direction as much as possible by means of reorganizing competitive market constraints. (As far as such integration cannot be reached, they agree to limitations of market forces by constraints established in a competitive-neutral manner.) While pursuing this goal of integration (respectively limitation) they are conscious that they share a co-responsibility in the field of politics with regard 
to prevalent general economic conditions. Accordingly, they commit themselves politically in that they, say, consistently support reform efforts towards an ecologically and socially sustainable market economy instead of blindly defending management liberties or financial advantages.

Thus, in our view, executives thinking along such reforming lines (altogether 10\%) do more justice to the structural conditions of a modern economic system than any others who were recorded, and this in a manner that is sustainable in both ethical and economic terms, and is critical and realistic at the same time. Particularly in the thinking pattern of the New Entrepreneur, we discern a manager type of the future who is well aware of ethical problems and also provides normative business ethics with a workable approach.

\section{The phenomenon of background economism}

The business-ethical thinking patterns outlined above represent idealized types - in the sense of Max Weber (1904) - of the existing argumentations requiring interpretation. For this reason, virtually none of the managers interviewed could be assigned to only one of the above thinking patterns. If secondary orientations were not taken into account, the distribution that (as in Fig. 1) refers to the dominant orientation alone, would provide an inadequate picture.

To begin with, one might be inclined to regard the ambivalences and inconsistencies that are expressed in such secondary orientations as a result of the type formation itself. After thorough examination we have, however, become convinced that these inconsistencies or "breaks" in the interviewees' business-ethical consciousness may actually be considered typical themselves. ${ }^{8}$ It would appear that such a consciousness must be imagined as many-layered, very much like the geological stratification of various sediments. Below the consciously advocated thinking patterns might be settled background convictions that are likely to be biographically older.

Characteristic differences with regard to incidence did not only occur with the primary (dominant) orientations but were also observed among certain secondary orientations and their relations with certain primary orientations (real types). The third but last line of Figure 2 lists the frequency in which the thinking pattern characterized in that particular column occurred as the secondary (additional) orientation of other types (the percentages refer to the sum-total of all interviewees); the last line of the table, however, shows the most frequent secondary thinking pattern of the type represented in the column (i.e. of the thinking pattern as primary orientation), insofar as a characteristic secondary orientation could be determined at all.

With reference to the four basic types, the picture is substantially different once the secondary orientations are taken into account. This is particularly true in the case of economism, which prima facie represents the inclination of a mere third of managers and entrepreneurs so that to begin with, we could infer a preponderance of conventionalist thinking patterns. All in all, however, economism proved to be an extraordinarily frequent thinking pattern in our study, with an overall incidence of $76 \%$ (addition of $24 \%$ and $52 \%)^{9}$

Apart from the Metaphysical Economists, it is especially the Conventionalists whose comments were often apt to reveal an additional faith in the "invisible hand" of the market - despite primarily (or superficially) conventionalist argumentations. Since such a faith in a "natural" or metaphysical (and not man-made or politically established) harmony does not appear to require any express justification in these cases but is regarded as a matter of course by its representatives and, as such, hardly noticed, we call this widespread form of subliminal market harmonism background economism.

Now, background economism calls for (conventional) personal ethics on the part of managers, i.e. the market does not automatically harmonize the pursuit of economic success with the demands of ethics. Yet, business success is seen as a necessary prerequisite for (and not, as with Metaphysical Economists, the epitome or the guarantor of business ethics. Responsible management seems to be a matter of creating as much profit as possible first of all - and, to be consistent - with complete disregard for any aspects that will not serve to achieve success; only then can ethical demands be satisfied. Thus, ethical considerations only come into play once profits can be distributed (which, of necessity, is done in a patronizing manner). Such a "charitable" 
or "alms-giving" ethics, however, is the equivalent of a compensatory or "repair" ethics (Mittelstrass, 1990: 36) which merely cures the symptoms. The question of how such profits which are then spent on "good causes" are generated, i.e. the ethical quality of the profit-making processes themselves, is systematically ignored. The guarantee that these processes are ethically good and proper is apparently again provided by the market. Conventionalists subscribing to background economism, then, may have room for, indeed even need of, business ethics but will only apply it after the profits have been made in accordance with a strict pursuit of success, and apply it to the distribution of such profits alone: the more successfully a company operates, "the better you can afford such ethical principles". Thus the business-ethical problem is characteristically cut in half; of course, those who argue along these lines will not perceive this bisection.

All in all, there are three versions of economism:

1. Its purest form is represented by the Metaplysical Manager. Here, what is ethically right is ultimately defined by the anonymous, suprapersonal conditions of market success, i.e. the free market's "will" is the embodiment of ethically responsible business operations. Since Metaphysical Managers believe in the metaphysics of the market and trust the wisdom of the market's "invisible hand" effectively to guide their entrepreneurial action in the right direction, they feel relieved of any businessethical responsibilities.

2. A version that is now more widespread but can be traced back to the same roots is that represented by the Instrumentalist. Here, the market is the guarantor of the realization of ethical demands, which are thought to be defined independently of the market. Instrumentalists take the economic success of "ethical" investments or concessions as a sign of the generally charitable work of this guarantor. They try to make clear, with the help of many examples, that long-term market success necessarily involves compliance with ethical standards.

3. Finally, conventionalists very often display the version of background economism. Here, ethics is not defined by the market, either, but market success is regarded as a necessary prerequisite for the satisfaction of extra-economic ethical standards, as well as for ethically (not economically) morivated sponsorship in the widest sense of the term.

\section{Opportunism or economism? A critical reinterpretation of US studies}

At the outset of this paper we posited that for methodological reasons, interviewees must be hypothetically granted a postconventional moral consciousness, i.e. the competence as well as the "good will" to make ethical judgements based on critical reflection. This, it would appear, is opposed by the results of several investigations into the morals of managers whose authors believe that they have detected an increasing trend towards "opportunism" or even "cynicism".

Baumhart (1961: 19) was the first researcher to confront interviewed managers with the grave reproach of cynicism. On the basis of concrete questions with a multiple choice of answers as to how interviewees would react in certain ethically delicate situations, he found out that interviewees regularly ascribe to themselves a distinctly "higher" ethical consciousness than to their "average" colleagues. Since, however, this difference between the assessment of oneself and of others is made by all of the interviewees and therefore mutually, Baumhart (1961: 16f.) concludes that what they think and do is more likely to correspond to their appraisal of "average" manager behaviour than to their selfdescription. This is why Baumhart (1961: 19) speaks of those managers' "double ethic". Insofar as this means that such managers consciously act in a manner that falls short of their own ethical awareness, it would indeed be expressive of a cynical atritude, since cynicism may be precisely defined as "acting against better knowledge" - or, as Sloterdijk (1983: 37) defines it in his brilliant Kritik der zynischen Vernunft [Critique of Cynical Reason]: "Cynicism is the enlightened false consciousness"; it is the consciousness of those who "have sacrificed their own better insight to outside 'constraints'" (p. 41).

Along the very same lines, Brenner and Molander (1977: 65) also conceive of cynicism as a matter whereby "apparently, economic values override ethi- 
cal values". Using largely the same research questions as Baumhart 15 years before them, they even believe that they could discern a "growing cynicism" among American managers. Posner and Schmidt (1987: 383) do not doube this postulate either. Including further, similar studies, they come to the conclusion that "a survey of the literature about the ethical dimensions of managerial decision-making tends to be somewhat discouraging:" In their empirical investigation into German executives, Kerber et al. (1986: 281ff.) similarly conclude that there was a pronounced trend towards ethical "opportunism".

Now, our thesis is that such alleged "cynicism" is in fact an expression of an economistic way of thinking that has a wide circulation (and is surely not confined to Swiss managers). As we have seen, economism is not at all synonymous with an "unethical", ethically uninterested, opportunistic or even cynical attitude. Quite on the contrary, it has its roots in a profound business-ethical commitment, thus representing a legitimation concept with a serious ethical claim. We think it is provable that the above-mentioned studies failed to grasp the deep structure of their interviewees' business-ethical mentalities. Owing to their inadequate research designs which are personalistically and conventionalistically reduced, they come to conclusions that do not do justice to the ethical quality of manager's thinking-patterns. We are going to furnish this proof by means of a reinterpretation of the results gathered from the responses to four selected statements that were used in a similar manner by the above-mentioned US studies.

Statement 1: "Sound ethics is good business in the long run"

To begin with, our critical reinterpretation is based on the fact that virtually all interviewees agreed with this statement, which was uniformly presented in precisely this formulation in all three studies: Baumhart (1961: 10), Brenner and Molander (1977: 62) and Becker and Fritzsche (1987: 293) (Fig. 3). In addition, Becker and Fritzsche's internationally comparative study also revealed that agreement was highest among American managers; a little less distinctive (but without any significant difference) was that of French managers; in comparison with

\begin{tabular}{lc}
\hline \multicolumn{1}{c}{ Studies } & Agreement \\
\hline Baumhart & $99 \%$ \\
Brenner/Molander & $>98 \%$ \\
Becker/Fritzsche & "general agreement"
\end{tabular}

Fig. 3. "Sound ethics is good business in the long run." (Statement 1).

those, German executives agreed to a slightly lesser extent again.

As we have seen, however, it is precisely in this empirically registered conviction of a nexus between ethics and long-term economic success that a typically economistic thinking-pattern is expressed: we have described this pattern as instrumentalism and found it quite frequently in our own investigation (as primary and secondary orientation with a total of $52 \%$ of interviewees) - although, in contrast to the American studies, we did not directly ask for agreement with the statement (which might have been rather suggestive; thereby we would probably have obtained an even higher rate of agreement, too). Evidently, the instrumentalistic-economistic way of thinking is internationally widespread among managers, and a phenomenon that occurs relatively constantly over time.

Now, it is remarkable that none of those studies checked the systematic status of Statement 1 with regard to its ethical relevance with any care. Only Baumhart (1961: 10) seems to notice at all that the postulate "Sound ethics is good business in the long run" is not, in the first instance, an ethical maxim but a strategic motive (of cleverness): "But don't conclude that the 'ethical' attitude revealed by these answers stems solely from a desire to do what is right because it is right." Brenner and Molander (1977: 62), on the other hand, are evidently caught up in an instrumentalistic bias themselves if they interpret Statement 1 as an ethical "standard". Yet at this expressive level of the statement this surely does not apply: an "ethical" course of action is taken precisely because and insofar as it is in the service of lasting profitability. To this extent, this is not a genuinely ethical orientation that accentuates the unconditionality of ethical principles, i.e. categorical imperatives, but an instrumentalization of ethics (or, to speak with 
Kant, a question of hypothetical imperatives). This is also shown in the fact that the application of "sound ethics" alone is considered, and it would be interesting to ask against what yardsticks this "soundness" is measured.

The view expressed in Statement 1 is not new in any case. As early as the beginnings of modern capitalist development, merchants adhered to the rule that "honesty is the best policy" - at least to the extent to which they were interested in a continual maintenance of business relations (Weber, 1972: 383, 727). If today, in the light of the ethics boom, managers increasingly highlight this time-tested commercial principle, then this may well simply be due to the present-day experience that "publicly exposed" (Dyllick, 1989: 15ff.) corporations have to strive for preserving their good names and to ensure the acceptance of their business activities by an increasingly sensitive and critical general public. Failing that, they may be ticked off by the media, boycotted by consumers, or lose personnel or at least their staff's commitment. This is why most contemporary managers soberly appear to view "ethics" as a strategic success factor - no more and no less. The range of management instruments is thus extended by "ethics" - as it was previously by "corporate culture". After all, today's catch-phrase is "soft is hard" (Peters and Waterman, 1982: 11).

Still, our historically founded interpretation of the instrumentalistic version of economism makes clear why Instrumentalists claim that their thinking pattern is a business-ethical legitimation concept, nonetheless, and therefore seems to be mere opportunism only on the face of it. The crucial point here is not the interviewees' perception of the matter of fact that "ethics" has partially to be accounted for reasons of managerial cleverness. Rather, the key point is the now conspicuous rash generalization of this partially plausible nexus into a universal "standard" used to provide the pursuit of economic success with legitimacy. This, however, reveals more than mere pragmatic cleverness: it reveals the subliminal affirmation of the premise of market metaphysics.

\section{Statement 2: "Whatever is good business is good ethics"}

Both Baumhart's and its successors' studies noted a variety of contradictions and incongruities which, in our view, cannot be traced back to opportunism or even "cynicism", either. Instead, they can easily be explained in terms of the different interpretations of the economistic nexus between ethics and long-term economy that are in circulation. According to both Baumhart (1961: 11f.) and Becker and Fritzsche (1987: 295), 10-15\% of managers agree not only with Statement 1 but also with Statement 2 (Fig. 4). This view implies that any "purposeful" use of "ethics" in business life would be superfluous. The fact that still about $10 \%$ of the interviewees clearly agreed to this statement, after all, appeared to irritate Baumhart (p. 10: "we wonder ...") since he interpreted it as an open avowal of an opportunistic point of view on the part of these managers: "This is the same as saying that if a thing makes money it is good." (p. 12). It would, however, hardly be plausible that some many interviewees agreed with this statement without themselves being convinced that this maxim could be ethically legitimized.

\begin{tabular}{lr}
\hline \multicolumn{1}{c}{ Studies } & Agreement \\
\hline Baumhart & $15 \%$ \\
Becker/Fritzsche & $<10 \%$ \\
\hline
\end{tabular}

Fig. 4. "Whatever is good business is good ethics." (Statement 2).

Baumhart does not seem to be able to explain the 15\% agreement with Statement 2. Again, our study may provide the basis for this explanation: obviously, managers will not bluntly agree with Statement 2 because they regard it as an admission of their own "low level of ethical ideas". Quite to the contrary, this agreement reflects their serious business-ethical claim - the same claim to legitimacy as that made by Metaphysical Managers. ${ }^{10}$ What else would they want to express in an interview about business ethics?

Yet why do Metaphysical Managers equate "good business" with "good ethics"? Let us recall: in this pure, original form of economism, the market is the embodiment of ethics. The methodically disciplined orientation towards long-term corporate success entails the subordination of managers to the anonymous market and for this reason the necessary banishment 
of any personal inclinations, interests and convictions - including not least those that are moral in nature. The strict metaphysicians among the managers will always regard those personal values as an expression of mere "arbitrariness": Metaphysical Managers are moral sceptics. For them, rationality and morality inhabit two different worlds. They do not think themselves or others capable of making rational judgements in ethical matters, just as conversely, they maintain that the influx of personal ethical considerations would only disrupt the functional rationality of the (suprapersonal) economy.

This ethical scepticism does not, however, plunge Metaphysical Managers into nihilism. After all, the strict pursuit of market success provides them with a safe ethical course. Indeed, they believe that the "arbitrary" character of their personal commitment will proportionally decrease with the degree to which they, as managers, submit themselves to the suprapersonal constraints of the market, i.e. consistently take their bearings from "ever lasting profitability" (Weber, 1972: 79). The verdict of the market functions as the substitute for any individual's ethical acts and decisions: "market economies instead of ethics" is the motto here. The crucial point is that in this manner, the Metaphysical Manager is in a position to link the strict and ceaseless pursuit of market success (profitability) with the central ethical idea of impartiality, which he thinks is perfectly realized in the idealized market. This is why he thinks that he is able to conclude that "the free market economy is the fairest economic system because decisions are taken by the market." "Thus the Metaphysical Manager considers the pursuit of economic success as completely and utterly beyond any ethical suspicions while at the same time regarding any personal ethical considerations within the framework of management as superfluous, indeed as ethically hazardous.

Yet how can an agreement with Statement 2 be brought under one umbrella with an agreement with Statement 1? The percentage of agreement with Statement 1 suggests that those managers who think along strictly economistic lines (agreement with Statement 2) must also have agreed that "sound ethics" has to be in the service of the assurance of long-term success although in their view, ethics ought to be eliminated from the world of business in principle. The key might be found in the specific interpretation of Statement 1 that the adjective "sound" suggests to interviewees. Managers inclined towards the type of the Metaphysical Manager are likely to recognize more soberly and clearly than Instrumentalists do that this cannot be a question of autonomous ethical consideration, but only of a clever (strategic) adaptation to the present conditions of the attainment and assurance of long-term success that determine the extent and manner of ethical considerations - how else could the pursuit of managerial success be the guarantor of ethics? Thus "pure" Metaphysical Economists do not as much as see an antagonism between the two statements, which, within the economistic legitimation pattern, is even more consistent.

Conversely, Instrumentalists obviously regard Statement 2 ("Whatever is good business is good ethics.") as irreconcilable with their own position (Statement 1). After all, they would like to give testimony of their ethical commitment as managers, which for them is a necessity from an actual business point of view alone. Moreover, the widespread agreement with Statement 1 and the simultaneous strong disagreement with Statement 2 may well be attributed to the fact that interviewees were not asked to respond to the statement, "Whatever is good business in the long run is good ethics." Economism, however, always implies a correspondence of long-term economy and ethics. Thus Instrumentalists in parricular emphasize again and again that "ethical" investments pay off in the long term but in the short term involve expenses and therefore lower profits. Brenner and Molander (1977: 69) report that $41 \%$ of interviewees link an ethical commitment with a short-term financial disadvantage, while another $16 \%$ are "neutral" towards this statement. This apprehension of a short-term lack of harmony between economy and ethics is likely to confirm Instrumentalists in their assumption that the appropriate ethical management can only be ensured if managers aim at the maintenance and extension of lasting profit opportunities (and this involves the calculation of one's own competitive position in comparison with the greatest possible number of competitors). ${ }^{11}$

Managers whose economism is only latent (background economism) will not be able to agree with Statement 2, either, for with them it is primarily a matter of their own ethical attitudes, without which ethical requirements cannot be satisfied. On the 
other hand, latent exponents of economism also agree that "sound ethics is good business in the long run" (Statement 1); for this thinking pattern will only permit any moral commitment once a solid financial basis has been achieved (cf. Section 3 above).

Statement 3: "The American business executive tends to ignore the great ethical laws as they apply immediately to his work. He is preoccupied chiefly with gain"

The studies mentioned above derive their cynicism thesis mainly from the discrepancy between the managers' mutual ethically negative assessment of one another and their self-assessment (cf. beginning of Section 4). In Baumhart's study (1961: 19) no less than "almost 50\%" of executives agree with Statement 3, which asks for an assessment of others. Brenner and Molander (1977: 62) also recorded an agreement with the identical statement by "close to half" of their interviewees. Finally, the managers interviewed by Becker and Fritzsche (1987: 293f.) both in the USA and in France and Germany showed a lesser degree of agreement, i.e. their response tended to be "neutral" (Fig. 5). According to the authors, this could have been a result of the respondents' lack of familiarity with the "great ethical laws".

\begin{tabular}{lc}
\hline \multicolumn{1}{c}{ Studies } & Agreement \\
\hline Baumhart & "almost 50\%" \\
Brenner/Molander & "close to half" \\
Becker/Fritzsche & "neutral" \\
\hline
\end{tabular}

Fig. 5. Managers "ignore the great ethical laws" and are "preoccupied chiefly with gain." (Statement 3).

Again, we are of the view that these results cannot generally be taken to reflect any "cynical" attitude on the part of managers at all. We maintain that the relatively high rate of agreement with Statement 3 finds a more adequate explanation in the widespread adherence to various versions of economistic thinking.

Thus Metaphysical Managers will even be able to subscribe to Statement 3 for ethical reasons if they include themselves, too, since from their point of view it is not necessary, but might in fact be hazardous, if the "great ethical laws" were "immediately" applied to management. They hold that they will best satisfy ethical requirements if they do not presume to engage in any arbitrary ethical actions themselves but leave these decisions to suprapersonal authorities such as the market or the law (cf. annotation 11).

Nor is an agreement with Statement 3 (in the sense of acknowledgement of a fact) in any way unlikely among Instrumentalists since as a rule, they tend to regard the "insight" that "ethics" is a success factor and thus a necessary aspect of management as relatively new and therefore as not yet very widespread. Then, however, there would be no contradiction with their agreement with Statement 1, as Brenner and Molander (1977: 62) evidently think when they interpret a simultaneous agreement with both statements as a "failure". Only in the highly unlikely case that Instrumentalists should include themselves in their agreement with Statement 3 would there be either an actual "failure" or - if this self-inclusion had been quite deliberate - the first substantiated case of cynicism!

The latent exponents of (background) economism, however, will have more difficulty understanding the ethical claim of pure economism, which bans morality from the business world on principle. For this reason they may well judge the behaviour of many of their colleagues as "unethical" - very much like social scientists to whom economism is an alien concept. The fact that they partially represent the same thinking pattern as the colleagues they thus disparage will therefore hardly enter their minds since their economistic convictions are subliminal and thus largely beyond the pale of their consciousness.

Statement 4: "Competition today is stiffer than ever. As a result, many businessmen find themselves forced to resort to practices which are considered shady, but which appear necessary to survive"

All those who consider ethics to be realized by means of a long-term economic course of action will 
never really regard too stiff a competition as ethically problematical - at least as long as they push their argument to its logical conclusion. This, however, would appear to be a somewhat rare occurrence, which is probably due to the fact that reality does not fit the bill of economistic "theory" all that easily. In Brenner and Molander's study (1977:62), $43 \%$ of American managers agreed with Statement 4, while among Becker and Fritzsche's respondents (1987: 294), 35\% of the American and French but $60 \%$ of the German executives agreed with the statement. In our study, too, $54 \%$ of the managers interviewed see themselves confronted at times with situations "in which they must make managerial decisions they actually regard as ethically questionable" - thus the wording of one of the questions that was asked (cf. Fig. 6).

Managers from

Agreement

$\begin{array}{ll}\text { the USA (according to Brenner/Molander) } & 43 \% \\ \text { the USA (according to Becker/Fritzsche) } & 35 \% \\ \text { France (according to Becker/Fritzsche) } & 35 \% \\ \text { Germany (according to Becker/Fritzsche) } & 60 \% \\ \text { Switzerland (according to Ulrich/Thielemann) } & 54 \%\end{array}$

Fig. 6. "Competition forces managers to resort to questionable practices." (Statement 4).

A good many economistically thinking managers thus believe that in principle, there is a harmonious relationship between the managerial pursuit of profits and therefore the adaptation to the constraints of market competition (market success and constant increase in competitiveness) on the one hand, and general ethical demands on the other. Nonetheless, day-to-day management occasionally or even regularly confronts them with tangible ethical dilemmas arising precisely from the factual constraints imposed upon them by the task of holding their own in a competitive market.

Managers who agreed with Statement 4 despite its contradiction of Statement 1 may be assumed to be less "pure" exponents of economism. Conversely, Metaphysical Managers do not as much as perceive the problem posed by Statement 4 . The reason for this is that for them, market success is not merely the guarantor of, or a necessary prerequisite for, an ethics defined elsewhere (i.e. T) outside the market $T$ which is the case with instrumentalism and background economism. Rather, they consider market success to be ethically legitimate in itself: market success actually defines what is ethically appropriate. Metaphysical Managers thus do not see any problems in sacrificing other values to the "necessity to survive"; they always encounter situations "in which I must take an ethically problematical decision." (A "pure" Metaphysical Economist should properly say, of course: "There are always situations in which I must take a decision which some people may regard as 'ethically problematic.')

Presumed that it is the normal case that the managers, confronted with Statement 4 , believe that the practices in question indeed are to be "considered shady", i.e. that there are in fact moral dilemmas, the distinctly higher rate of agreement with this statement among German managers $(60 \%)$ in comparison with US and French executives implies that such a "pure" economism is rarer among them. On the other hand, Becker and Fritzsche (1987: 294) report that virtually all American and French but only $26 \%$ of the German managers clearly reject the following statement: "The businessman exists only for one purpose: to create and deliver value satisfactions at a profit to himself. If what is offered can be sold at a profit, then it is legitimate. The spiritual and moral consequences of the businessman's actions are none of his concern." It would therefore have to be assumed that it is precisely Germany that has a high proportion of particularly strict exponents of economism (although the reservation "at a profit to himself" should actually rather bother them).

These partly contradictory results may well be ascribed to the fact that the German sample was drawn up in accordance with methods different from those used for the US and French samples, and that the figures are neither comparable nor in themselves representative, as Becker and Fritzsche (1987: 295) stress themselves. In any case, the vagueness or even obscurity of the German managers' responses indicates that investigations into managerial ethics demand more exacting data recording and evaluation methods than mere questions eliciting agreement or disagreement with certain statements. In our opinion, executives' business-ethical 
thinking can only be more profoundly understood if the reasons explaining certain responses are elucidated and condensed into thinking patterns. We have attempted to show that an approach along such lines would pave the way for an essential contribution towards research into business ethics.

\section{Results in brief}

(1) We think that we have demonstrated that traditional investigations into the problem of "how ethical are businessmen?" lack a systematic theoretical conception of the central business-ethical reconciliation problem (personalistic and conventionalistic reduction) and therefore arrive at partially serious misjudgements.

(2) Against the background of the systematic conception that has served as the basis of this study, it has been revealed that rather than opportunism or even cynicism, it is economism in its various versions which, as the most important business-ethical thinking pattern displayed by managers, will explain why the managers in question regard any more or less strictly success-oriented courses of action as ethically legitimate.

(3) With a view to pedagogic efforts in the field of business ethics, aimed at developing an ethical consciousness among executives, the first priority is to take those managers' claims to legitimation seriously and to form an adequate understanding of their business-ethical thinking patterns - their business ethos. Provided our theses are valid and the actual target group of an ethical education consists predominantly of persons with an economistic bent, a fruitful business-ethical dialogue would have to start with such managers being confronted with their very own thinking patterns, and this means: with a critique of economism.

(4) Only against the background of a systematic thematization of the business-ethical reconciliation problem can adequately differentiated business-ethical thinking patterns such as that of the Reformers be recognized. It is precisely those thinking patterns displayed by genuinely "leading" managers that prove to be at once "realistic" (i.e. economically imposable) and ethically sustainable. Insofar as empirically supported differentiations of such real, recorded thinking patterns point above and beyond the present-day state of the business-ethical discussion, they will ultimately lead the way towards an acceptable normative business ethics.

\section{Appendix: Data base}

\section{Business Sectors}

Services

22

(Financial Services incl.)

(8)

Trade

8

Industry

30

$\Sigma 60$

Company Size
Management Position

$\begin{array}{lr}\text { Chairman or executive } & \\ \text { member of the board } & 28 \\ \text { Executive Officers } & 26 \\ \text { Vice-Presidents } & 6 \\ & \Sigma 60\end{array}$

\section{Notes}

1 Apart from the above-mentioned studies by Baumhart (1961) and Posner and Schmidt (1987), this also applies to the two subsequent studies by Brenner and Molander (1977) and Becker and Fritzsche (1987), both of which took up Baumhart's question. Like these US studies, the German investigation by Kaufmann, Kerber and Zulehner (1986) was also based on questions concerning personal ethics and thus largely reached the same conclusions (opportunism, cyni- 
cism). These conclusions will be subjected to scrutiny in Section 4 of this paper.

2 The face that such a personalistically reduced approach leads to contradictions finds particularly clear expression in an Italian study (ASFOR, 1989), which is otherwise based on a highly differentiated moral-philosophical approach and doesn't fall victim to a conventionalist reduction at all. Hinterhuber (1991) reports that, on the one hand, this study reaches the conclusion that managers in private industry regard the "welfare of the company" as the first "ethical preference", while the "respect for an individual's fundamental values" comes only second (Hinterhuber, 1991: 476f.). On the other hand, the same study claims that some two thirds of Italian managers have to be characterized as people who "recognize the individuals' inviolable spaces, rights and liberties which protect their possessors' ethical integrity" (Hinterhuber, 1991: 477). If, however, the study maintains that the "welfare of the company" is placed, without reconciliation, higher than this general ethical principle quoted above, then we consider this proof that the unconditional claim of this (deontological) ethical principle is precisely not recognized by the majority of interviewees.

3 The data base is exposed in the appendix.

* A virtually paradigmatic expression of the idea of a "pure" logic of management can be found in Erich Gutenberg (1929: 39ff), the founder of the "classical" German theory of business administration. According to this idea, management is only disturbed by the personal influences on the part of the "psychophysical subject" (i.e. the executive), who must therefore be "eliminated" from the theory of business administration. Cf. Ulrich (1989) and Thielemann (1990).

$\vdots$ The following passages characterized by quotation marks and printed in italics are verbatim quotations of the managers interviewed.

"Friedrich A. von Hayek (1979), who conceived of competition as a "discovery procedure", was a particularly pronounced exponent of such a revelation theory of the market.

7 Our sample only contained one single manager $(2 \%)$ with this dominanc thinking pattern, which was, however, displayed as an addirional, secondary orientation by an impressive $38 \%$ of the interviewees. By the way, none of the female managers interviewed could be classified as Metaphysical Economists at the dominant level, whereas $100 \%$ of them showed an idealistic thinking pattern at least as a secondary orientation?

8 Only the New Entrepreneurs did not display any, or at least no distinctive, additional orientations. In our view, this may be regarded as further evidence of the validity of this obviously equilibrated thinking pattern.

9 The corresponding figures of secondary conventionalism are partly related to other types of conventionalism and thetefore cannot be summarized.

10 The $17 \%$ ratio of Metaphysical Managers found in our study seems to correspond to the ratios of agreement with statement 2 quite well.

"Yet Metaphysical Managers. too, would have to find it difficult to agree. For those amongst them who spare the matter a little thought will soon realize that, say, any business transacted by the Mafia is also "good business". Metaphysical Managers will usually try to avoid this embarrassment by pointing out - as a rule, in terms of suggestions rather than arguments - that the Mafia's activities are not really aimed at long-term, i.e. temporally unlimited business success, that the Mafia is not interested in infinite capital interest returns, and that it therefore does not unconditionally bow to the verdict of the market. Moreover, Metaphysical Managers may indicate, without seriously changing their legitimation pattern, that in contrast to the Mafia, they are perfectly willing to remain within the confines of the law. Yet again, this does not affect their view that management need not concern itself with ethical considerations - after all, they say, "with the legal department, we virtually have the police on the premises". And, indeed, about half of the strict Metaphysical Managers interviewed in our study displayed legalism as their secondary orientation.

\section{References}

ASFOR (eds.): 1989, Il manager di fronte ai problemi etici (Milan).

Baumhart, R. C.: 1961, 'How Ethical Are Businessmen?', Harvard Business Review 39(4), 6-19, 156-176.

Becker, H. and D. J. Fritzsche: 1987, Business Ethics: A Cross-cultural Comparison of Managers' Attitudes', Journal of Business Ethics 6(6), 289-295.

Brenner, S. N. and E. A. Molander: 1977, 'Is the Ethics of Business Changing?", Harvard Business Review 55(1), 5771.

Dyllick, Th: 1989, Management der Umweltbeziehungen. Öfentliche Auseinandersetzungen als Herausforderung (Gabler, Wiesbaden).

Friedman, M.: 1970, 'The Social Responsibility of Business Is to Increase Its Profits', The New York Time Magazine, September 13, 32-3, 122-126 (Reprinted in: M. Snoeyenbos, R. Almender and J. Humber (eds.): 1983, Business Ethics (Promethens, New York), pp. 73-99).

Gutenberg, E.: 1929, Die Untemehmung als Gegenstand betriebswirtschafticher Theorie (Spaeth und Linde, Berlin).

Habermas, J.: 1984, The Theory of Communicative Action, Vol. 1, Reason and The Rationalization of Society (Beacon, Boston).

Habermas, J.: 1986, 'Entgegnungen', in: A. Honneth and $\mathrm{H}$. Joas (eds.), Kommunikatives Handelin. Beiträge zu Jürgen Habermas" "Theorie des kommunikativen Handelns" (Suhrkamp, Frankfurt a.M.), pp. 327-405.

Habermas, J.: 1987, The Theory of Communicative Action, Vol. 2, 
Lifeworld and System: A Critique of Functionalist Reason (Beacon, Boston).

Hayek, v. F. A. 1979, Law, Legislation and Liberty, Vol III, The Political Order of a Free Society (Routledge \& Kegan Paul, London).

Hinterhuber, H. H.: 1991, 'Die Ethik in der Unternehmung: Probleme, Prinzipien und Einstellungen der italienischen Führungskräfte', in: H. Steinmann and A. Löhr (eds.), Unternehmensethik, 2nd edition (Poeschel, Stuttgart), pp. $471-479$.

Kaufmann, F.-X., W. Kerber and P. M. Zulehner: 1986, Ethos und Religion bei Führungskräften (Kindt, München).

Kohlberg, L.: 1981, Essays on Moral Development, Vol. 1, The Philosophy of Moral Development (Harper \& Row, San Francisco).

Mittelstrass, J:: 1990, 'Wirtschaftsethik oder der erklärte Abschied vom Ökonomismus auf philosophischen Wegen', in: P. Ulrich (ed.), Auf der Suche nach einer modernen Wirtschaftsethik (Paul Haupt, Bern/Stuttgart), pp. 17-38.

Peters, Th. J. and R. H. Waterman, Jr.: 1982, In Search of Excellence. Lessons from America's Best-Run Companies (Harper \& Row, New York).

Pfriem, R.: 1989, 'Das Ökologieproblem als Gegenstand einer möglichen Unternehmensethik', in: E. Seifert and R. Pfriem (eds.), Wirtschaftsethik und okologische Wirtschaftsforschung (Paul Haupt, Bern/Stuttgart), pp. 111-128.

Posner, B. Z. and W. H. Schmidt: 1987, 'Ethics in American Companies: A Managerial Perspective', Joumal of Business Ethics 6(6), 383-391.

Rawls, J:: 1981, A Theory of Justice (Harvard University Press, Cambridge).

Sloterdijk, P.: 1983, Kritik der zynischen Vernunft (Suhrkamp, Frankfurt a.M.).

Smith, A.: 1976a, The Theory of Moral Sentiments, edited by D. D. Raphael and A. L. Macfie, Glasgow Edition Vol. I (Clarendon, Oxford).

Smith, A.: 1976b, An Inquiry into the Nature and the Causes of the Wealth od Nations, edited by R. H. Campbell and A. S. Skinner, Glasgow Edition Vol. II (Clarendon, Oxford).

Thrielemann, U.: 1990, 'Die Unternehmung als ökologischer Akteur? Ansatzpunkte ganzheitlicher unternehmensethi- scher Reflexion. Zur Aktualität der Theorie der Unternehmung Erich Gutenbergs', in: J. Freimann (ed.), Ökologische Herausforderung der Betriebstuirtschafislehre (Gabler, Wiesbaden), pp. 43-72.

Ulrich, P.: 1987, Transformation der ökonomischen Vernunft. Fortschrittsperspektiven der modemen Industriegesellschaft, 2nd edition (Paul Haupt, Bern/Stuttgart), third ed. forthcoming 1993.

Ulrich, P.: 1989, 'Der spezielle Blick der Allgemeinen Betriebswirtschaftslehre für die ökonomischen Dinge der Unternehmensführung - Ein sozialökonomischer Ansatz', in: W. Kirsch and A. Picot (eds.), Die Betriebswirtschaftslehre im Spannungsfeld zwischen Generalisierung und Spezialisierung, Festschrift Edmund Heinen zum 70. Geburtstag (Gabler, Wiesbaden), pp. 137-154.

Ulrich, P.: 1991, 'Der kritische Adam Smith - im Spannungsfeld zwischen sittlichem Gefühl und ethischer Vernunft', in: A. Meyer-Faje and P. Ulrich (eds.), Der andere Adam Smith. Beiträge zur Neubestimmung von Ökonomie als Politischer Ökonomie (Paul Haupt, Bern/Stuttgart), pp. 145-190.

Ulrich, P. and U. Thielemann: 1992, Ethik und Erfolg. Unternehmensethische Denkmuster von Führungskräften - eine empirische Studie (Paul Haupt, Bern/Stuttgart).

Weber, M.: 1904, 'Die "Objektivität" sozialwissenschaftlicher und sozialpolitischer Erkenntnis', Gesammelte Aufsatzer zur Wissenschaftslehre (edited by J. Winckelmann), 4th edition 1973 (Mohr, Tübingen), 146-214.

Weber, M.: 1920, 'Dic protestantische Ethik und der Geist des Kapitalismus', Gesammelte Aufsätze zur Religionssoziologie I (Mohr, Tübingen), pp. 17-205.

Weber, M.: 1972, Wirtschaft und Gesellschaft (edited by J. Winckelmann), 5th edition (Mohr, Tübingen).

\author{
Institut für Wirtschaftsethik, \\ Hochschule St. Gallen \\ Guisanstrasse 11, \\ CH 9010 St. Gallen \\ Switzerland.
}

